\title{
Perancangan Sistem Informasi Inventaris Barang Di Laboratorium Fakultas Teknik Uniska Kediri
}

\author{
Arif Frahmana Hakim', Yudo Bismo Utomo², Diah Arie Widhining Kusumastutie ${ }^{3}$ \\ 1,2,3 Teknik Elektro, Fakultas Teknik, Universitas Islam Kadiri Kediri \\ E-mail: \\ diahariewk@uniska-kediri.ac.id
}

\begin{abstract}
Abstrak - Perkembangan dunia teknologi informasi dan dunia digital saat ini sangatlah pesat, salah satu contohnya yaitu komputer. Dengan adanya komputer semua pekerjaan manusia dalam hal pelayanan, pengolahan dan penyimpanan data menjadi sangat mudah dan cepat, karena sudah terkomputerisasi. Akan tetapi, laboratorium Fakultas Teknik di Uniska Kediri dalam merekap inventaris barang masih menggunakan cara manual, sehingga merepotkan pihak admin laboran dalam merekap karena membutuhkan waktu yang lama dalam merekap barang yang ada di laboratorium tersebut. Hasil yang di peroleh dari penelitian ini adalah aplikasi Sistem Informasi Inventaris Barang yang dibuat telah sesuai dengan kebutuhan fungsional yang ada di laboratorium Fakultas Teknik Uniska Kediri, yaitu memudahkan admin laboran dalam merekap inventaris barang meliputi alat-alat peraga praktikum yang ada di laboratorium tersebut secara terkomputerisasi, sekaligus memantau kondisi barang tersebut masih layak atau tidak untuk dibuat praktikum.
\end{abstract}

Kata Kunci - Laboratorium, Terkomputerisasi, Sistem Informasi, Aplikasi, Inventaris Barang.

\begin{abstract}
The development of the world of information technology and the digital world today is very fast, one example of which is computers. With the existence of computers all human work in terms of service, processing and storing data becomes very easy and fast, because it is computerized. However, the Faculty of Engineering laboratory at Uniska Kediri in recapitulating goods inventory still uses manual methods, making it difficult for admin labors to recap because it takes a long time to recapitulate the items in the laboratory. The results obtained from this study are the Inventory Information System application of goods that are made in accordance with functional requirements that exist in the laboratory of the Faculty of Engineering in Uniska Kediri, namely facilitating laboratory administrators in recapitulating goods inventory including computerized teaching aids in the laboratory, while monitoring the condition of the goods that are still feasible or not to be made practicum.
\end{abstract}

Keywords - Laboratory, Computerized, Information Systems, Application, Inventory of Goods.

\section{PENDAHULUAN}

Perkembangan di dunia teknologi informasi dan dunia digital saat ini sangat pesat, salah satu dari teknologi yang dimaksud adalah komputer. Komputer merupakan suatu alat elektronik untuk mengolah data menjadi sebuah informasi yang berguna bagi penggunanya. Disamping itu, komputer mempunyai keunggulan dalam mendeteksi kesalahan data yang diolah dan dapat melakukan pekerjaan diluar kemampuan manusia, sehingga keterlambatan suatu pekerjaan dapat dihindari [1].

Penggunaan komputer harus disesuaikan dengan kebutuhan organisasi yang memakainya, baik software maupun hardware agar komputer dapat dimanfaatkan sebaik mungkin . Zaman yang semakin maju, semakin bertambah pula kebutuhan manusia akan teknologi yang dapat membantu memecahkan masalah yang dihadapi. Begitu pula dalam kemajuan informasi, dengan adanya komputer akan mempunyai peranan yang sangat penting dalam memecahkan suatu masalah. Maka dari itu, penggunaan komputer saat ini sudah banyak digunakan oleh organisasi dalam hal pelayanan, pengolahan dan penyimpanan data [2]. 
Seperti halnya di kampus Universitas Islam Kadiri sebagai salah satu Perguruan Tinggi Swasta yang ada di kota Kediri, pengelolaan laboratorium yang ada di Uniska Kediri masih menggunakan cara manual, yaitu admin laboran merekap di buku tulis. Cara tersebut dapat dilakukan kalau admin laboran tidak lupa menaruh rekapan tersebut ditempat yang semestinya dan aman, akan tetapi jika rekapan tersebut hilang, maka membutuhkan waktu yang lama buat admin laboran merekap data lagi.

Untuk mengatasi permasalahan tersebut diatas, maka peneliti akan merancang sistem informasi inventaris barang yang ada di Laboratorium Fakultas Teknik Uniska Kediri yang bertujuan untuk mendata alat-alat peraga yang dibuat praktikum dengan sistem yang terkomputerisasi, sehingga prosesnya lebih efektif dan efisien serta hemat waktu dan hemat tenaga sebagai media penyedia penyampaian informasi.

Dengan adanya aplikasi ini diharapkan dapat membantu admin laboran untuk merekap inventaris barang meliputi alat-alat peraga praktikum yang ada di Laboratorium Fakultas Teknik Uniska Kediri, sekaligus memantau kondisi barang tersebut masih bagus atau layak dibuat praktikum atau tidak. Karena laboratorium merupakan sarana penunjang proses praktikum mahasiswa yang ada di Fakultas Teknik Uniska Kediri [3].

Rumusan masalah dari penelitian ini adalah bagaimana cara merancang sistem informasi inventaris barang yang ada di laboratorium Fakultas Teknik Uniska Kediri sesuai dengan kebutuhan yang diinginkan. Supaya penelitian ini tidak meluas, maka batasan masalah dalam penelitian ini meliputi, 1) obyek yang dijadikan penelitian berada di laboratorium Fakultas Teknik Uniska Kediri; 2) Inventaris barang yang akan dijadikan penelitian berisi tentang aset atau alat-alat peraga yang dibuat mata kuliah praktikum yang ada di Fakultas Teknik Uniska Kediri; dan 3) Pembacaan data inventaris barang alat peraga praktikum menggunakan barcode scanner tipe 39 di smartphone android dengan koneksi bluetooth.

\section{METODE PENELITIAN}

Metode yang akan di pakai dalam penelitian ini menggunakan metode penelitian tindakan atau action research. Metode action research adalah suatu metode yang bertujuan untuk memecahkan suatu masalah supaya segera dapat diambil tindakan perbaikan [4]. Tahap dari metode action research ini adalah sebagai berikut :

1. Identifikasi Masalah

Penelitian ini dimulai dengan melakukan identifikasi masalah terlebih dahulu untuk menentukan masalah apa yang sedang terjadi di laboratorium Fakultas Teknik Uniska Kediri, sehingga peneliti ingin merancang aplikasi sistem informasi inventaris barang yang ada di laboratorium tersebut.

2. Studi Literatur

Setelah dilakukan identifikasi masalah, tahap selanjutnya dilanjutkan dengan studi literatur. Dalam tahap ini, peneliti melakukan studi literaur dengan cara membaca artikel maupun jurnal yang berkaitan dengan sistem informasi laboratorium.

3. Pengumpulan Data

Dalam tahapan ini dilakukan pengumpulan data dengan cara melakukan wawancara langsung dengan pihak terkait, yaitu admin laboran. Tujuannya adalah aplikasi yang akan dibuat nantinya bisa memenuhi kebutuhan penggunanya.

4. Perancangan Sistem

Dalam penelitian ini, untuk perancangan sistem akan menggunakan use case diagram.

5. Implementasi Sistem

Tahap implementasi sistem merupakan penerjemahan dari perancangan sistem yang telah dibuat sebelumnya oleh peneliti di tuang ke dalam bahasa pemrograman visual basic yang bisa dikenali oleh komputer. Tahapan inilah yang merupakan tahapan secara nyata dalam mengerjakan suatu sistem aplikasi.

6. Pengujian Sistem

Tahapan akhir dari penelitian ini adalah pengujian sistem, yang bertujuan untuk menjamin apakah aplikasi yang telah dibuat dapat terintegrasi dengan baik dan siap digunakan oleh stakeholder. Pengujian sistem pada penelitian ini menggunakan black box testing.

Langkah-langkah dari penelitian ini dapat dilihat pada gambar 1 berikut ini: 


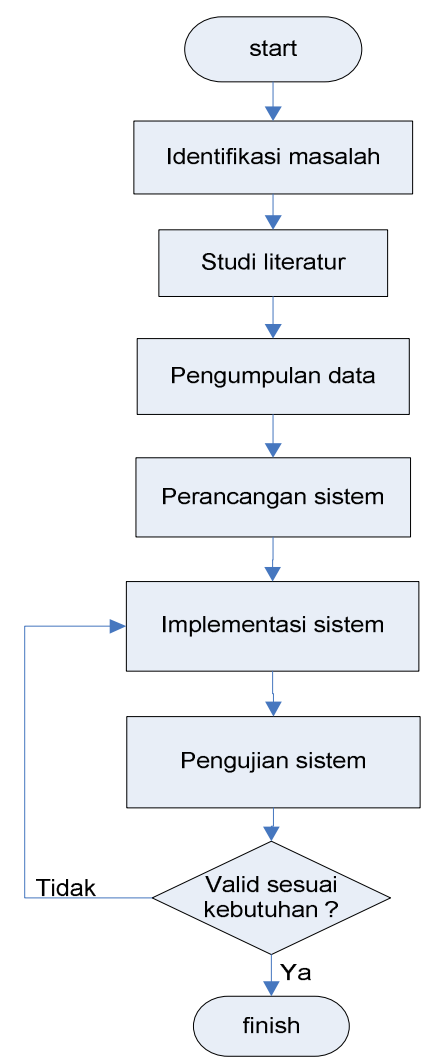

Gambar 1. Alur Metode Penelitian Action Research

\section{HASIL DAN PEMBAHASAN}

\subsection{Identifikasi Masalah}

Setelah penulis melakukan penelitian di laboratorium Fakultas Teknik Uniska Kediri, maka didapatkan masalah yang dihadapi oleh admin laboran, karena pengelolaan data barang yang ada di laboratorium Fakultas Teknik Uniska Kediri sampai saat ini masih menggunakan cara manual. Oleh karena itu, peneliti menemukan beberapa kelemahan dari sistem yang lama dan adanya indikasi dapat terjadinya masalah, seperti yang ditunjukkan pada tabel 1 berikut:

Tabel 1. Identifikasi Masalah Pada Laboratorium FT Uniska Kediri

\begin{tabular}{|c|c|c|c|}
\hline No & Aktifitas & Kelemahan & Masalah yang terjadi \\
\hline 1. & $\begin{array}{l}\text { Pendataan } \\
\text { inventaris barang }\end{array}$ & $\begin{array}{l}\text { Proses pendataan } \\
\text { inventaris barang } \\
\text { di laboratorium } \\
\text { Fakultas Uniska } \\
\text { Kediri masih } \\
\text { dilakukan dengan } \\
\text { cara manual } \\
\end{array}$ & $\begin{array}{l}\text { a. Terjadinya keterlambatan informasi data jika } \\
\text { ada barang yang tiba-tiba rusak belum ada } \\
\text { pembenahan penulisan pada laporan } \\
\text { informasi. } \\
\text { b. Terjadinya keterlambatan informasi data jika } \\
\text { ada barang baru di laboratorium Fakultas } \\
\text { Teknik Uniska Kediri. }\end{array}$ \\
\hline 2. & $\begin{array}{l}\text { Hubungan admin } \\
\text { laboran dengan } \\
\text { kepala lab, dosen } \\
\text { dan mahasiswa } \\
\text { Fakultas Teknik } \\
\text { Uniska Kediri }\end{array}$ & $\begin{array}{l}\text { Tidak adanya } \\
\text { sistem yang } \\
\text { memberikan } \\
\text { informasi yang } \\
\text { cepat dan akurat } \\
\text { tentang kondisi } \\
\text { barang, ketika } \\
\text { kepala lab, dosen, } \\
\text { dan mahasiswa } \\
\text { membutuhkan } \\
\text { data secara } \\
\text { mendadak. }\end{array}$ & $\begin{array}{l}\text { Jika masalah tersebut tidak segera di atasi, maka } \\
\text { terdapat kesalahpahaman informasi antara admin } \\
\text { laboran dengan stackholder. }\end{array}$ \\
\hline
\end{tabular}




\subsection{Perancangan Sistem}

Perancangan sistem dalam penelitian ini menggunakan Use case diagram. Use case diagram adalah suatu teknik perancangan sistem yang menggambarkan secara ringkas, siapa saja yang menggunakan sistem dan apa saja yang bisa dilakukannya [5]. Dalam penelitian ini, user terdiri dari 2 aktor, yaitu aktor admin laboran dan admin kepala laboratorium. Aktor admin laboran dapat mengelola data barang yang ada di laboratorium dan merekap data tersebut ke dalam laporan. Sementara aktor kepala laboratorium hanya dapat melihat laporan saja, sebagaimana ditunjukkan pada gambar 2 berikut ini:

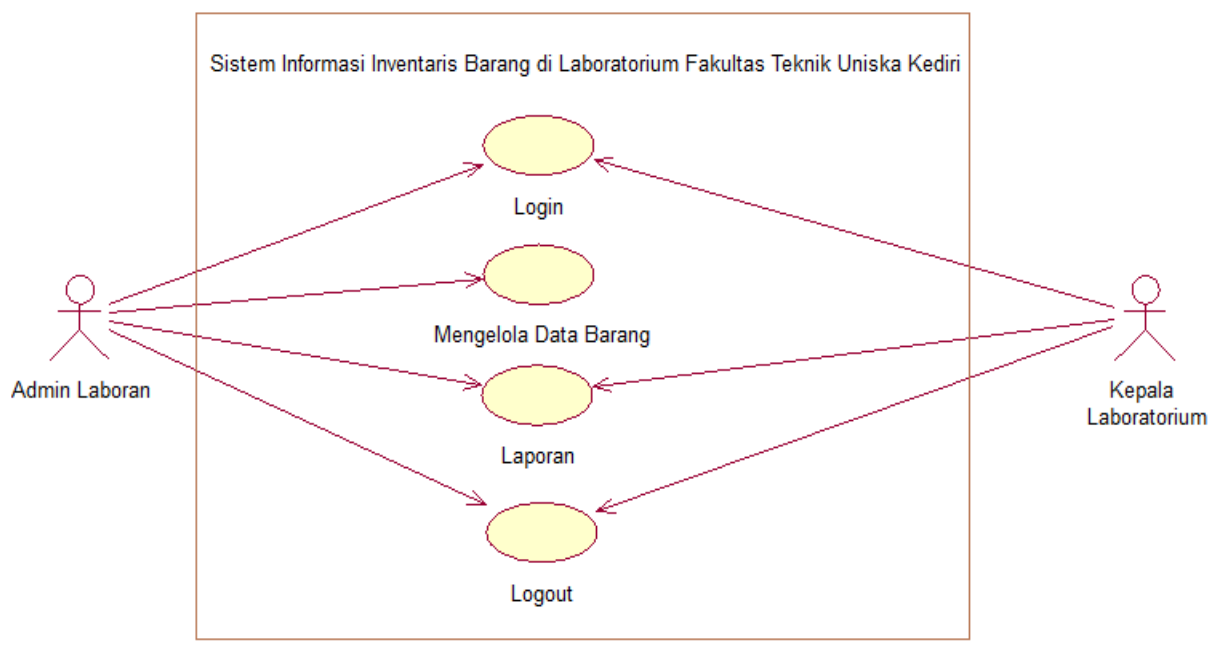

Gambar 2. Use Case Diagram Sistem Informasi Inventaris Barang

\subsection{Perancangan Algoritma Menu Login}

Perancangan algoritma (Pseudocode) fungsi login ini menjelaskan alur kerja sistem saat user akan masuk kedalam sistem. Berikut perancangan algoritma (pseudocode) fungsi dari login:

\section{Mulai}

Tampilkan halaman login

Input username dan password

If ( user = admin laboran) Then

Masuk halaman utama Mengelola Data Barang

Elseif (user = kepala laboratorium) Then

Else

Masuk halaman laporan

Tampilan pesan username atau password salah

Kembali ke halaman login

Endif

Selesai

\subsection{Perancangan Algoritma Menu Mengelola Data Barang}

Perancangan algoritma (Pseudocode) menu mengelola data barang ini menjelaskan alur kerja sistem saat user admin laboran melakukan input dan update barang. Berikut perancangan algoritma (pseudocode) menu mengelola data barang:

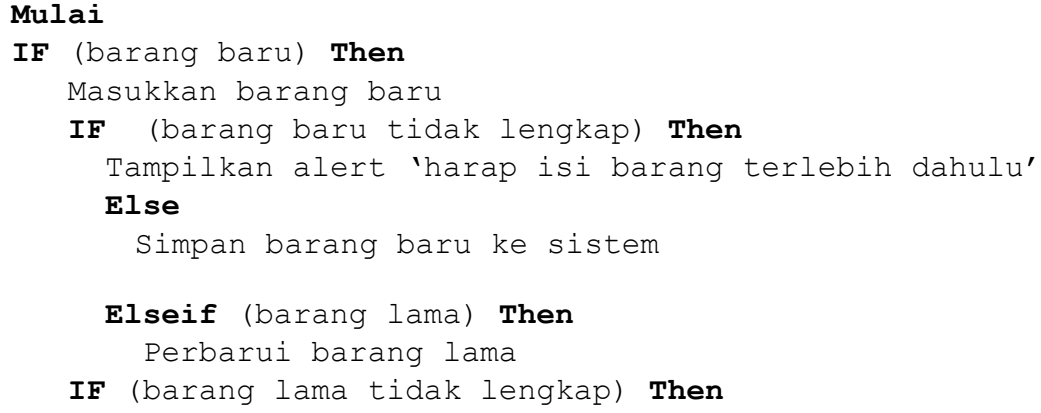




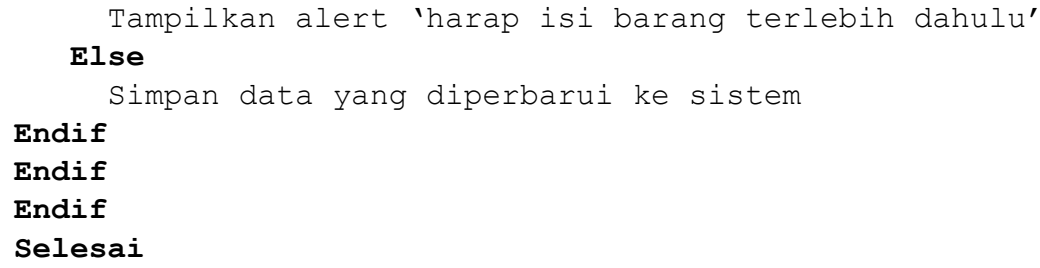

\subsection{Perancangan Algoritma Menu Laporan}

Perancangan algoritma (Pseudocode) menu laporan ini menjelaskan alur kerja sistem saat user admin laboran dan kepala laboratorium melakukan generate laporan inventaris barang. Berikut perancangan algoritma (pseudocode) menu laporan:

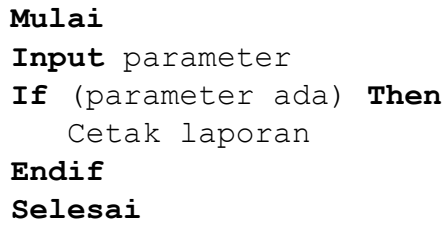

\subsection{Implementasi Sistem}

Berikut ini hasil implementasi dari aplikasi sistem informasi inventaris barang yang telah dibuat dan akan diterapkan di laboratorium Fakultas Teknik Uniska Kediri.

1. Tampilan Menu Login

Pada tampilan utama dari aplikasi ini terdapat menu login, yang berarti proses untuk mengakses dengan memasukkan username dan password, supaya mendapatkan hak akses masuk ke dalam aplikasi. User atau pengguna yang mendapatkan hak akses untuk melakukan login adalah admin laboran dan kepala laboratorium. Tampilan dari menu login akan ditunjukkan pada gambar 3 berikut ini.

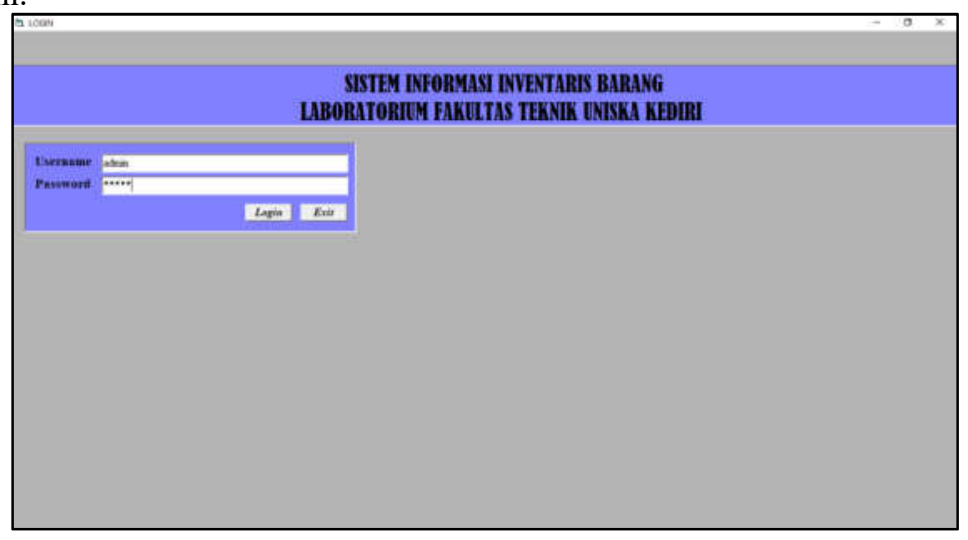

Gambar 3. Halaman Menu Login

2. Tampilan Menu Mengelola Data Barang

Setelah pengguna admin laboran melakukan login, maka aplikasi akan beralih ke menu halaman mengelola data barang. Pada menu halaman ini, jika admin laboran ingin memasukkan data barang, admin hanya menginputkan pada kolom form Nama barang, jumlah, tahun pengadaan, sumber dana, kepemilikkan, kondisi baik, kondisi rusak, jenis dan keterangan. Pada tahap berikutnya, setelah admin laboran mengisi pada masing-masing kolom form, selanjutnya klik tombol "Simpan". Secara otomatis, data yang sudah diinputkan langsung tersimpan kedalam database laporan. Tahap selanjutnya jika ingin membatalkan pendataan nama barang yang ingin dibatalkan atau menghapus klik tombol "Batal". Selanjutnya jika ingin melakukan pencarian data barang, dapat dengan cara memasukkan kata kunci nama barang lalu klik tombol "Cari". Pada tahap berikutnya jika ingin melakukan pengeditan pada data nama barang, admin laboran dapat mengklik tombol "Edit", lalu data pada akan berubah sesuai dengan yang sudah di edit. Tahap berikutnya, jika admin laboran sudah cukup untuk mendata barang dan ingin menyudahi 
klik tombol "Logout" lalu program akan kembali ke menu halaman pertama atau ke menu "login". Tampilan dari menu mengelola data barang akan ditunjukkan pada gambar 4 berikut ini.

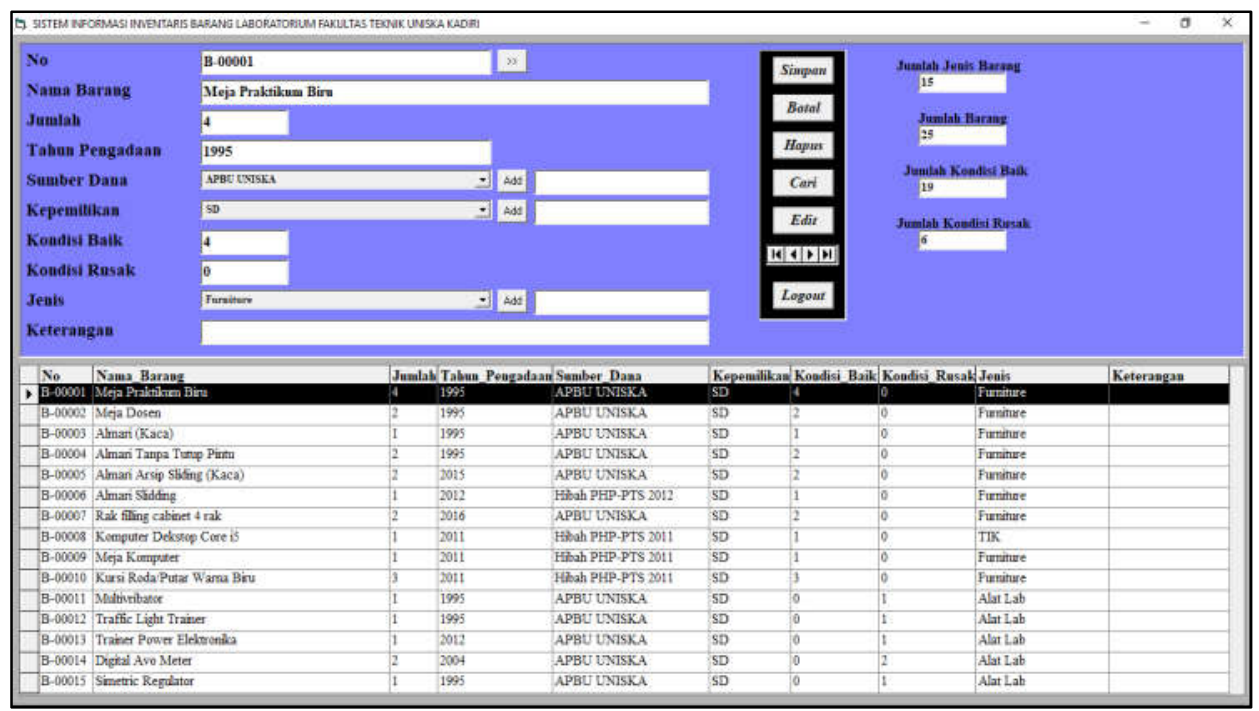

Gambar 4. Halaman Menu Mengelola Datang Barang

3. Tampilan Menu Laporan

Pada halaman menu laporan ini ditujukan untuk pengguna admin laboran dan kepala laboratorium. Menu laporan ini diperoleh dari admin laboran menginputkan nama barang, jumlah, tahun pengadaan, sumber dana, kepemilikkan, kondisi baik, kondisi rusak, jenis dan keterangan pada halaman menu mengelola barang.

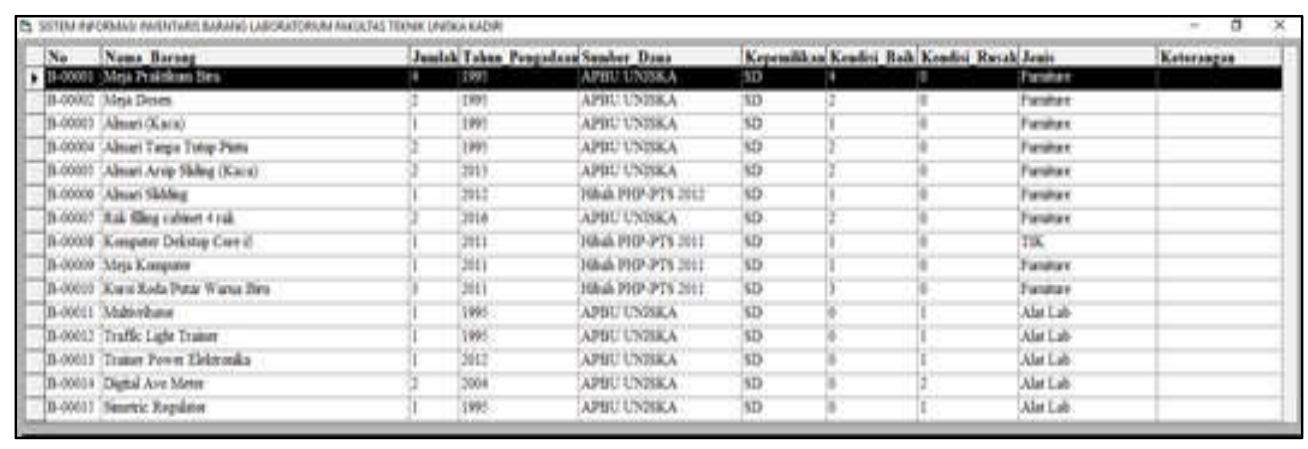

Gambar 5. Halaman Laporan

\section{3..6 Pengujian}

Setelah aplikasi sistem informasi inventaris barang yang sudah dirancang, maka tahap selanjutnya akan dilakukan pengujian. Pada penelitian ini, tahap pengujian menggunakan metode black box testing. Tahap pengujian ini bertujuan untuk mengetahui apakah aplikasi yang sudah dibuat telah memenuhi kabutuhan dari pengguna atau tidak.

1. Pengujian Sistem Login

Tabel 2. Pengujian Sistem Login

\begin{tabular}{|l|l|l|l|l|l|l|}
\hline No & $\begin{array}{l}\text { Skenario } \\
\text { Pengujian }\end{array}$ & Test Case & $\begin{array}{l}\text { Hasil Yang } \\
\text { Diharapkan }\end{array}$ & $\begin{array}{l}\text { Hasil } \\
\text { Pengujian }\end{array}$ & Status \\
\hline 1 & Memasukan & Username : & Sistem akan & Sesuai & Valid \\
& Username dan & admin & & memberikan hak \\
& Password, lalu & Password : & $\begin{array}{l}\text { akses ke menu } \\
\text { sistem berikutnya. }\end{array}$ & & \\
& langsung klik & admin & & & \\
& "Login" & & & \\
\hline
\end{tabular}




\begin{tabular}{|c|c|c|c|c|c|}
\hline 2 & \begin{tabular}{l}
\multicolumn{2}{l}{ Mengosongkan } \\
Username dan \\
Password, \\
langsung \\
"Login" klik
\end{tabular} & $\begin{array}{l}\text { Username :- } \\
\text { Password: - }\end{array}$ & $\begin{array}{lr}\text { Sistem menolak } \\
\text { akses login dan } \\
\text { menampilkan } \\
\text { pesan "Username } \\
\text { Atau Password } \\
\text { Yang Anda } \\
\text { Masukan Salah, } \\
\text { Silahkan coba lagi" }\end{array}$ & $\begin{array}{l}\text { Sesuai } \\
\text { harapan }\end{array}$ & Valid \\
\hline 3 & $\begin{array}{l}\text { Klik } \\
\text { "Exit" }\end{array}$ & Klik & Keluar dari sistem & $\begin{array}{l}\text { Sesuai } \\
\text { harapan }\end{array}$ & Valid \\
\hline
\end{tabular}

2. Pengujian Sistem Mengelola Data Barang

Tabel 3. Pengujian Sistem Mengelola Data Barang

\begin{tabular}{|c|c|c|c|c|c|}
\hline No & Skenario Pengujian & Test Case & $\begin{array}{ll}\text { Hasil } & \text { Yang } \\
\text { Diharapkan }\end{array}$ & $\begin{array}{l}\text { Hasil } \\
\text { Pengujian }\end{array}$ & Status \\
\hline 1 & $\begin{array}{l}\text { Memasukan data } \\
\text { barang yang akan di } \\
\text { simpan, lalu klik } \\
\text { tombol "simpan". }\end{array}$ & Klik & $\begin{array}{lr}\text { Sistem berhasil } \\
\text { menyimpan } & \text { data } \\
\text { barang yang telah di } \\
\text { inputkan r dan } \\
\text { sistem } & \text { akan } \\
\text { memberikan } & \text { info } \\
\text { "Data Baru } & \text { Telah } \\
\text { Tersimpan" } & \text { dan } \\
\text { ditampilkan } & \text { ke } \\
\text { dalam laporan. } & \end{array}$ & $\begin{array}{l}\text { Sesuai } \\
\text { harapan }\end{array}$ & Valid \\
\hline 2 & $\begin{array}{l}\text { Menghapus isi dari } \\
\text { text box dan combo } \\
\text { box , dengan klik } \\
\text { tombol "batal". }\end{array}$ & Klik & $\begin{array}{l}\text { Text box dan combo } \\
\text { box akan terhapus, } \\
\text { kecuali text box } \\
\text { yang "no". }\end{array}$ & $\begin{array}{l}\text { Sesuai } \\
\text { harapan }\end{array}$ & Valid \\
\hline 3 & $\begin{array}{l}\text { Menghapus data } \\
\text { dalam datagrid, } \\
\text { dengan klik tombol } \\
\text { "hapus". }\end{array}$ & Klik & $\begin{array}{l}\text { Data di dalam } \\
\text { datagrid akan } \\
\text { membutuhkan } \\
\text { konfirmasi, ketika } \\
\text { kita klik "cancel" } \\
\text { data tidak akan } \\
\text { terhapus dan ketika } \\
\text { kita klik "ok" data } \\
\text { akan terhapus dari } \\
\text { datagrid. }\end{array}$ & $\begin{array}{l}\text { Sesuai } \\
\text { harapan }\end{array}$ & Valid \\
\hline 4 & $\begin{array}{l}\text { Melakukan pencarian } \\
\text { data dengan } \\
\text { memasukan kata } \\
\text { kunci barang, lalu } \\
\text { kita klik tombol } \\
\text { "cari". }\end{array}$ & Klik & $\begin{array}{l}\text { Data yang kita cari } \\
\text { muncul dengan di } \\
\text { tunjukan oleh anak } \\
\text { panah. }\end{array}$ & $\begin{array}{l}\text { Sesuai } \\
\text { harapan }\end{array}$ & Valid \\
\hline 5 & $\begin{array}{l}\text { Melakukan edit data } \\
\text { yang ada pada } \\
\text { datagrid dengan } \\
\text { malakukan pencarian } \\
\text { data dulu untuk di } \\
\text { tampilkan di text box } \\
\text { atau combo box dan } \\
\text { kita edit data,setelah } \\
\text { itu kita klik tombol } \\
\text { "edit" }\end{array}$ & Klik & $\begin{array}{l}\text { Data yang ada pada } \\
\text { datagrid akan } \\
\text { berubah sesuai data } \\
\text { yang sudah kita } \\
\text { edit. }\end{array}$ & $\begin{array}{l}\text { Sesuai } \\
\text { harapan }\end{array}$ & Valid \\
\hline
\end{tabular}


3. Pengujian Sistem Logout

Tabel 4. Pengujian Sistem Logout

\begin{tabular}{|l|l|l|l|l|l|}
\hline No & Skenario Pengujian & Test Case & $\begin{array}{l}\text { Hasil Yang } \\
\text { Diharapkan }\end{array}$ & $\begin{array}{l}\text { Hasil } \\
\text { Pengujian }\end{array}$ & Status \\
\hline 1 & $\begin{array}{l}\text { Pengguna melakukan } \\
\text { logout dengan klik } \\
\text { tombol "logout". }\end{array}$ & $\begin{array}{l}\text { Program akan } \\
\text { kembali ke menu } \\
\text { login. }\end{array}$ & $\begin{array}{l}\text { Sesuai } \\
\text { harapan }\end{array}$ & Valid \\
\hline
\end{tabular}

Setelah dilakukan pengujian rancangan aplikasi, maka tahap selanjutnya yaitu pengujian kelayakan, apakah rancangan aplikasi sistem informasi inventaris barang ini layak atau tidak untuk diterapkan di Laboratorium Fakultas Teknik Uniska Kediri. Untuk pengujian kelayakan ini dilakukan proses kuisioner terhadap 100 responder. Aspek yang ditanyakan pada kuisioner kepada responder, yaitu: tampilan aplikasi, kemudahan pemakaian dan tingkat respon aplikasi.

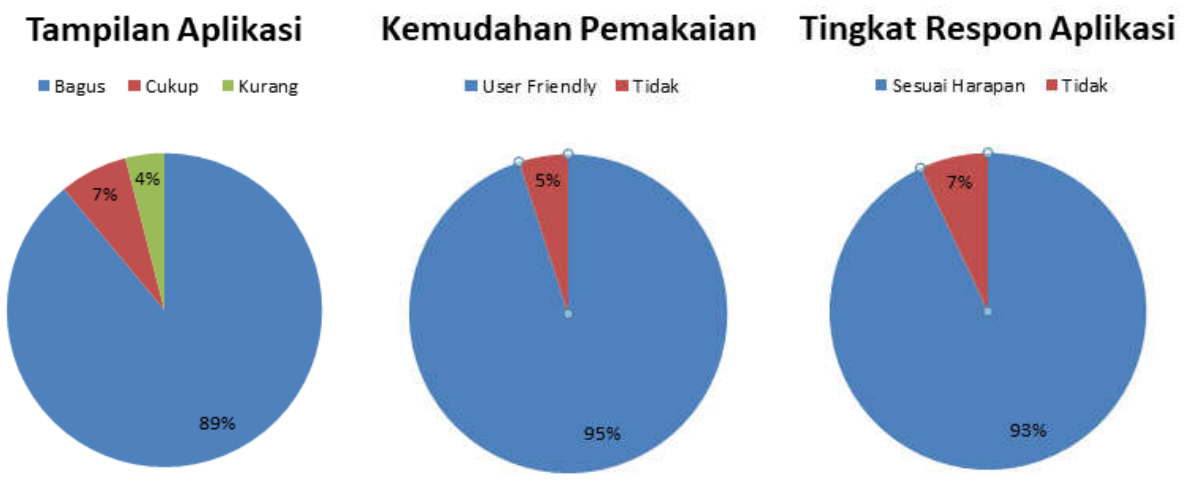

Gambar 6. Grafik Pengujian Kelayakan

Dari grafik diatas menyatakan bahwa aplikasi ini sangat bermanfaat dalam membantu kinerja admin laboran dalam mengolah data barang yang ada di laboratorium Fakultas Teknik Uniska Kediri.

\section{SIMPULAN}

Berdasarkan pembahasan yang telah diuraikan diatas, maka dapat diambil beberapa kesimpulan sebagai berikut:

1. Aplikasi sistem informasi inventaris barang yang telah dibuat ini, telah mampu memberikan kemudahan dari pihak admin laboran sebagai pengelola laboratorium dalam hal mengolah data inventaris barang yang ada di laboratorium Fakultas Teknik Uniska Kediri, sehingga informasi yang diberikan cepat dan tidak membutuhkan waktu yang lama dibandingkan dengan sistem yang manual.

2. Aplikasi yang telah dibuat ini, sudah terintegrasi dengan baik dan siap digunakan oleh admin laboran untuk mengolah data inventaris barang yang ada di Laboratorium Fakultas Teknik Uniska Kediri.

\section{SARAN}

Untuk pengembangan lebih lanjut dan penyempurnaan dari aplikasi sistem informasi inventaris barang di laboratorium yang telah dibuat, maka terdapat saran sebagai berikut:

1. Perlu menambahkan inputan data peminjaman barang dan pengembalian barang, supaya informasi yang diberikan dari aplikasi lebih lengkap dan akurat ke penggunanya.

2. Aplikasi yang dibuat pada penelitian ini berupa desktop, maka pengembangan penelitian selanjutnya dapat dijalankan pada aplikasi berplatform android untuk mendukung revolusi industri 4.0 . 


\section{DAFTAR PUSTAKA}

[1] Rohayati, dan Irwandi, Agus. 2016. Perancangan dan Implementasi Sistem Informasi Inventaris Laboratorium. Jurnal INTEKNA. Vol. 16, No. 2, November 2016.

[2] Arel, R.A, Chandra, M.S., dan Fajar, P. 2017. Analisis dan Perancangan Sistem Informasi Manajemen Gudang Pada PT Mitra Pinasthika Mulia Surabaya. Jurnal Pengembangan Teknologi Informasi dan Ilmu Komputer. Vol. 2, No. 2, Februari 2017.

[3] Meriana, Desiyani, dkk. 2015. Program Aplikasi Persediaan Barang Pada PT Panji Surya Abadi. Jurnal TICOM. Vol 3. No 3. Mei 2015.

[4] Utomo, Yudo Bismo, dkk. 2016. Perancangan Customer Relationship Management Pada Klinik. Jurnal Multitek Indonesia. Vol 10. No 1. Maret 2016.

[5] Adelia, Siti R., Gunawan, A., dan Asep, H. 2017. Sistem Informasi Inventaris Barang Pada RSUD Soreang. Prosiding SNATIF. Universitas Muria Kudus. April 2017. 